16. Verhunova, V.A. (Ed.) (2015). Poltavske tovarystvo silskoho hospodarstva (Zhurnaly zasidan z 4 bereznia 1901 r. po 22 hrudnia 1910 r.) [Poltava Society of Agriculture (Meeting logs from March 4, 1901 to December 22, 1910)], 3, 2 [in Ukrainian].

17. Samorodov, V.M. (2015). Poltavske silskohospodarske tovarystvo (1865-1929 rr.): istoriia, zvytiahy, pershopostati [Poltava Agricultural Society (1865-1929): history, customs, pervades]. Poltava: Dyvosvit [in Ukrainian].

18. Gurevich, M. (Ed.) (1923). Selskoye khozyaystvo Ukrainy [Agriculture of Ukraine]. Kharkov: Izdat. Otdel N.K.Z [in Russian].

19. Geyduka, D. (Ed.) (1867). Selskokhozyaystvennyy sbornik. Zemledelcheskiy zhurnal, izdavayemyy Poltavskim selskokhozyaystvennym obshchestvom [Agricultural collection. Agricultural journal published by the Poltava Agricultural Society], 1, 2, 3, 4-5, 6 [in Russian].

20. Sosnovskiy, M. (1897). Poltavskoye selskokhozyaystvennoye obshchestvo. 1865-1895 gg. [Poltava Agricultural Society. 1865-1895]. Poltava: Tipo-litogr. L. Frishberga [in Russian].

21. (1866). Statisticheskiy vremennik Rossiyskoy imperii [Statistical temporary of the Russian Empire]. Sankt-Peterburg: Izd-ye TsSK MVD [in Russian].

22. Tikhomirov, V.A. (1887). Istoricheskaya zapiska o deyatelnosti Poltavskogo selskokhozyaystvennogo obshchestva s $1865 \mathrm{~g}$. po $1887 \mathrm{~g}$. [istorical note on the activities of the Poltava Agricultural Society from 1865 to 1887]. Poltava: Tip. nasledn. N. Pigurenko [in Russian].

23. Yakymenko, M.A. (2009). Poltavske silskohospodarske tovarystvo: orhanizatsiina struktura ta osnovni napriamky diialnosti (1865-1917 roky) [Poltava Agricultural Society: Organizational Structure and Main Activities (1865-1917)]. Istorychna pam'iat - Historical Memory, 1, 46-53 [in Ukrainian].

Одержано 26.04.2019.

УДК 94:271.2-384](477.83) «1922/1944»(092)

\section{Березанська Ірина,}

кандидат історичних наук, викладач кафедри історії та культури України berezanska.im@gmail.com

https://orcid.org/0000-0002-7182-5750

Державний вищий навчальний заклад «Переяслав-Хмельницький державний педагогічний університет імені Григорія Сковороди», вул. Сухомлинського, 30, м. Переяслав-Хмельницький, Київська обл. Україна, 08401
DOI https://doi.org/10.31470/2415-35672019-46-164-173

\section{Berezanska Iryna,}

Candidate of Historical Sciences, a lecturer of Department of History and Culture of Ukraine berezanska.im@gmail.com

https://orcid.org/0000-0002-7182-5750

Pereiaslav-Khmelnytskyi Hryhorii Skovoroda State Pedagogical University,

30, Sukhomlynsky Str.,

Pereiaslav-Khmelnytskyi, Kyiv region,

\title{
ДУШПАСТИРСЬКА ТА ГРОМАДСЬКА ДІЯЛЬНІСТЬ О. ОМЕЛЯНА КОВЧА У МІСТІ ПЕРЕМИШЛЯНИ (1922-1944 pp.)
}

\author{
Служіння \\ о. Омеляна людям, незалежно \\ від віку, \\ національності, релігійних переконань свідчить про його
}


непересічну особистість праведника. Він служив ближнім незалежно від обставин. У кожній людині він бачив Божий образ. Свреї назвали його праведником Украӥни, поляки парохом Майданека, а Синод Спископів УГКЦ проголосив його покровителем греко-католицьких священиків України.

\section{(Владика Венедикт (Алексійчук), Спископ- помічник Львівської архиєпархї̈ УГКЦ))}

У статті проаналізовано особливості душпастирської та громадської діяльності греко-католицького священника міста Перемишляни на Львівщині Омеляна Ковча у міжвоєнний період. Особливу увагу зосереджено на його діяльності при різних окупаційних режимах: польському, радянському та німецькому.

Важливим історичним джерелом при розкритті досліджуваної проблематики стали спогади очевидиів тогочасних подій, які зберігаються в Перемишлянському історико-краєзнавчому музеї. Завдяки спогадам жителів міста М. Зацичного, С. Мацишин, О. Прибили, М. Шкільника нам вдалося ознайомитися з етнічним складом населення міста Перемишляни, життям і побутом його мешканщів під час польської, радянської та німецької влади, періодом перебування о. Омеляна Ковча у концтаборі Майданек.

Його душпастирська діяльність служить яскравим прикладом людяності, відкритості. Щирими проповідями Хрестової віри, він заслужив глибоку шану і повагу не тільки серед українщів, але $i$ поляків, євреїв, німиів. Омелян Ковч був активним громадським діячем, захисником украӥнських звичаїв, традщиій. За його ініціативи відкрито у місті Перемишляни Народний дім, засновано організацію «Пласт», драматичний гурток, кооперативні курси.

Ключові слова: Омелян Ковч, праведник України, євреї, парафія, душпастирська діяльність.

\section{PASTORAL AND PUBLIC ACTIVITIES OF FATHER OMELIAN KOVCH IN PEREMYSHLIANY (1922-1944)}

The article analyzes the peculiarities of pastoral and public activity of the Greek Catholic priest of Peremyshliany, Lviv region, Omelian Kovch in the interwar period. Particular attention is paid to his activities under different occupation regimes: Polish, Soviet and German.

An important historical source in the disclosure of the investigated issues were the memories of eyewitnesses of the events of that time, which are stored in Peremyshliany Museum of History and Local History. Thanks to the memoirs of the inhabitants of town M. Zatsycnyi, S. Matsyshyn, O. Prybyly, M. Shkilnyk, we were able to get acquainted with the ethnic population of Peremyshliany, life of its inhabitants during the Polish, Soviet and German rule, during the stay of Fr. Omelian Kovch at the Maidanek concentration camp.

His pastoral activity is a prime example of humanity, openness. With the sincere preaching of the Cross Faith, he earned a deep respect not only among Ukrainians, but also Poles, Jews, Germans. Omelian Kovch was an active public figure, a defender of Ukrainian customs and traditions. At his initiative, the People's House was opened in Peremyshliany, the "Plast» organization, a drama club, cooperative courses were founded.

Keywords: Omelian Kovch, righteous of Ukraine, Jews, parish, pastoral activity.

Діяльність греко-католицької церкви на початку XX ст. була спрямована на піднесення національно-культурного відродження в західноукраїнських землях. Незважаючи на політику Польщі щодо населення західноукраїнських земель, грекокатолицька церква та іiі священники були безпосередніми учасниками політичного, 
економічного і культурного відродження краю. Одним із них був греко-католицький священник міста Перемишляни на Львівщині о. Омелян Ковч.

Омелян Ковч відомий своєю релігійною та суспільно-культурною діяльністю, був чудовим проповідником, мужнім захисником інтересів та прав вірян своєї парафії, людиною щирої і відкритої душі. о. Ковч вів відкриту боротьбу з німецькою окупаційною владою за порятунок єврейського населення містечка Перемишляни, за що Сврейська рада України надала йому 9 вересня 1999 р. звання «Праведник України».

Актуальність теми дослідження обумовлена недостатнім висвітленням у наукових розвідках постаті Омеляна Ковча. Метою статті $є$ аналіз душпастирської та громадської діяльності пароха міста Перемишляни упродовж 1922-1944 рр.

Діяльність греко-католицького священника Омеляна Ковча частково стала предметом дослідження вітчизняних науковців В. Біласа [2], В. Бірчака [3], В. В'ятровича [3], І. Гнідик [15], К. Горбачової [5], Ж. Ковби [7], Л. Зеліско [6], В. Литвина [8], В. Мацелюха [9], І. Саківського [14], І. Стасюк [15] та ін.

Омелян Ковч народився 20 серпня 1884 р. у селі Космач Косівського повіту на Гуцульщині у родині священника Григорія Ковча та Марії Яскевич-Волфельд. Закінчивши початкову школу у селі Космач, він продовжив навчання у Львівській гімназії. Упродовж 1905-1911 р. О. Ковч навчався в колегії св. Сергія та Вакха завдяки матеріальній підтримці митрополита греко-католицької церкви Андрея Шептицького. До прийняття духовного сану Омелян Ковч одружився 3 Марією-Анною Добрянською. У шлюбі подружжя виховувало шестеро дітей - трьох синів і трьох дочок [3].

О. Ковч був священником у Галичині, пізніше у Боснії. Під час Першої світової війни вступив до Української галицької армії, ставши військовим капеланом Бережанського коша, пройшовши з ним всі військові випробування [6, с. 309]. У спогадах полковник УГА Роман Волинський згадував: «Молодий отець Омелян Ковч був повний енергії та сил. Не було кутка в коші, де наш духівник не з'являвся б кілька разів на день. Щоранку, відслуживши Літургію, поспішав до шпиталю. Щодня можна було його бачити на полі вправ, у канцелярії, в магазинах, він був чи не найкращим помічником у виховній роботі» $[8$, с. 95$]$.

31922 р. по 1943 р. Омелян Ковч служив парохом міста Перемишляни на Львівщині. В містечку проживало багато національностей - українці, поляки, цигани, євреї, кілька німецьких родин. 3 приходом у нову парафію, отець Ковч активно зайнявся релігійною та суспільно-культурною діяльністю. Йому вдалося знайти кошти на відновлення церкви, будівництва будинку «Просвіта». За його ініціативою було створено Український банк, який мав забезпечити фінансову незалежність української громади міста [3]. Омелян Ковч опікувався міською організацією «Пласт», за його підтримки утворюється драматичний гурток, діють кооперативні курси, проводяться Євхаристійні здвиги, з'їзди товариства «Сокіл» $[14$, с. 37].

Допомагав о. Ковч бідним, опікувався сиротами. Він більше дбав про своїх парафіян, ніж за себе. Про будинок отця Ковча парафіяни говорили: «Над тією хатою ангели кружляють» [8, с. 96]. Це був невеликий будинок, в якому оселилося 8 чоловік - отець Ковч із дружиною і шістьма дітьми. Тут знаходили прихісток сироти та студенти. Своїми благими намірами Омелян Ковч показував приклад любові до ближнього i взаємодопомоги.

Парох Перемишлян був чудовим проповідником. У своїх проповідях він умів зазирнути до серця кожного парафіянина, дати потрібні настанови, викликаючи серед прихожан глибокошановану повагу i вдячність. Про чудові проповіді $є$ спогади I. Пришляка, який називав його златоустом. «Умів тішити, розвеселити і навернути майже кожну душу до Бога. Про Всевишнього творця і пресвяту Богородицю говорив так ревно, що люди плакали 3 жалю та радості. Я багато разів відвідував Унів, де отець Ковч часто гостював. Там у своїх славетних проповідях він кидав світло Христової віри, говорив про любов та пошану до Бога, до рідної церкви і свого народу» [15, с. 69]. 
14 березня 1923 р. Польща отримала юридичні права на Східну Галичину. У зв'язку 3 цим, поляки у містах і селах розвішували листівки, в яких сповіщалося про входження Галичини до складу Польщі на 25 років. Отець Омелян Ковч побачивши таку афішу на дереві, навпроти входу до церкви, зірвав іiі. На його вчинок надійшла скарга в суд. За свідка о. Ковч взяв польського пароха, не повідомивши йому про це. Прийшовши до суду польський священник не міг зрозуміти причину його виклику, як свідка. О. Ковч звернувся до нього з такими словами: «Це була Велика П'ятниця, в нас винесена плащаниця і виставлені Найсвятіші Тайни. Йду до церкви, а хтось обернувшись задком до Св. Тайн, читає якийсь папір. Мене кинуло в лють, і я здер той папір, а тепер виходить, що то є протидержавний вчинок. Як би Ви, отче, вчинили у такому випадку?». Польський священник відповів, що діяв би так само. Так, О. Ковча звільнили від обвинувачень [14, c. 37].

Багато уваги отець Ковч приділяв катехизації молоді, яка була спрямована на вивчення основ християнського віровчення. Парох навчав дітей в школі основам релігії. Незважаючи на перешкоди, які здійснювала польська влада, Омелян Ковч не полишав прагнення ознайомлювати дітей з основами християнства, змінюючи місце проведення занять на церкву або свій будинок [15, с. 69].

Будучи захисником інтересів та прав парафіян, він часто своїми діями викликав переслідування з боку польської влади, яка бачила небезпечне зростання авторитету пароха серед вірян. Переслідування, обшуки в його домівці не могли зламати міцний дух і прагнення О. Ковча до піднесення культурного розвитку українців. Інколи поляки ставили за приклад Омеляна Ковча своїм ксьонзам. За свої проповіді, в яких засуджував політику Польщі по відношенню до населення Галичини, священник потрапив у Бережанську тюрму.

Парафіяни міста не завжди розуміли пароха, вони хотіли помститися польській владі за причинені їм кривди. Омелян Ковч засуджував дії парафіян, які обкрадали польські родини: «Невже ж впродовж двадцяти років я вас так виховував?! Ви задивились на тих босяків, що тепер прийшли до нас. Мені соромно за вас перед Господом Богом. Коли у вас $€$ хоч трішки патріотизму й совісті, то я прошу ще сьогодні повернути все тим людям, від яких ви забрали» [5].

Прихід радянської влади у 1939 р. приніс хвилю нових змін у повсякденне життя населення міста Перемишляни. Незважаючи на утиски нової влади Омелян Ковч організував Євхаристійний конгрес парафіян та Йорданський похід на річку, де було встановлено великий хрест, прикрашений синьо-жовтими стрічками. Радянська влада хотіла заарештувати священника, але відкладала цей термін, враховуючи великий авторитет пароха на Перемишлянщині [9].

У червні 1941 р. після Служби Божої енкаведисти почали проводити арешти місцевого населення. Омеляну Ковчу вдалося втекти від їхніх переслідувань. Його переховували українців, евреї, поляки. НКВС написав оголошення, в якому обіцяло винагороду тим, хто вкаже місце, де переховується священник. Переховували о. Ковча i його доньок доти, поки більшовики не покинули Перемишлянщину [9].

Омелян Ковч був людиною щирої і відкритої душі, про що свідчить його допомога політичним в'язням, чисельність яких зростала під час Другої світової війни. За його вказівкою дружина і дочки варили обіди у себе вдома для в'язнів. о. Ковч зумів переконати тюремну адміністрацію, що його допомога має християнський характер [14, c. 38].

Через декілька днів у місто ввійшли німецькі війська. Місцеве населення раділо відступу комуністів. На цю подію Омелян Ковч так відреагував: «Не дуже радійте, на місце одного «добродія» прийшов інший, тільки гудзики в мундирах змінились» [8, с. 97].

Німеччина воювала за «життєвий простір», щоб винищити євреїв і взяти під свій контроль слов'ян. 31941 р. відбувається фізичне винищення єврейського населення, а 3 1942 р. звільнення територій від українців і поляків [7, с. 8]. 
3 приходом німців у Галичину запровадився новий порядок та етнічні назви. Замість українців, поляків, євреїв, німців з’явилися «арійці» і «неарійці». Вищою расою вважалася арійська. У гітлерівській Німеччині найвищими представниками арійців вважали корінних німців. «Неарійцями» називали євреїв, циган, їх планували винищити після того як німці отримають від них всю користь від їхньої примусової праці [7, с. 59].

Увійшовши у Перемишляни нацисти, здійснювали заходи по винищенню євреїв міста. Омелян Ковч звернувся до місцевого населення 3 проханням не співпрацювати 3 новою владою, відмовитися від участі у антиєврейських акціях [2]. У своїх проповідях отець Ковч відкрито засуджував політику німців щодо винищення єврейського населення. Священник намагався захистити євреїв міста від переслідувань і знищення. Він особисто переховував євреїв, видавав їм фальшиві метрики про хрещення, що давало їм шанс на порятунок. Омелян Ковч ще до приходу німецької влади мав великий авторитет у єврейської спільноти.

У Перемишлянах люди старшого віку пам'ятають як отець Ковч рятував євреїв від знищення. У жовтні 1941 р. в міській синагозі зібралися євреї на службу, група СС оточила будівлю. Зачинивши двері, німці підпалили споруду з євреями всередині. До Омеляна Ковча прибігли євреї із проханням про допомогу. Дійшовши разом із сином до синагоги, О. Ковч закричав німецькою мовою до есесівців, щоб відійшли, і сам почав відкривати двері. Для німців такий вчинок священника був несподіванкою. Цей факт підтверджено спогадами очевидців подій, зокрема дочки Омеляна Ковча Марії-Анни Ковч-Баран, яка видала книгу про тогочасні події [7, с. 139].

Свій відкритий протест проти німецького свавілля О. Ковч виклав у листі Гітлеру, вимагаючи отримати дозвіл на відвідування євреїв у гето. За це його заарештували та відправили у Львівську в'язницю на Лонцького [1, с. 125].

В період німецької акції в містечку Перемишляни проживало близько 7000 осіб єврейської національності, які перебували в замкненій дільниці, що отримала назву гето. Тут була єврейська рада, поліція. На місто було здійснено близько шести нападів нацистських сотень, після кожного з них біля 1000 осіб єврейського населення вивозили за місто, в ліс, і там розстрілювали [13, 3 арк.].

Допомогти звільнити Омеляна Ковча із в'язниці намагався Андрей Шептицький, але тюремна влада, дозволяла священнику отримати звільнення лише тоді, коли він відмовиться від допомоги євреям. Це суперечило поглядам отця Ковча, він не погодився на це, залишившись і далі в тюремному ув'язненні. Зберігся діалог того часу між О. Ковчем і працівником в'язниці: «Ви знали, що євреїв хрестити заборонено?» - «Не знав». - «А тепер знаєте»? - «Знаю». - «Будете далі їх хрестити»? - «Буду» [8, с. 98].

У серпні 1943 р. Омеляна Ковча перевезли до концтабору «Майданек» поблизу Любліна. Крім важкої фізичної роботи, отець Ковч сповідував в'язнів, благословляв священною водою людські останки перед спалюванням. Омелян Ковч користувався великим авторитетом серед в'язнів [8, с. 99].

25 березня 1944 р. в концтаборі «Майданек» перестало битися серце грекокатолицького священника Омеляна Ковча. Проте, жертовна діяльність о. Ковча 3 порятунку євреїв під час Другої світової війни, залишиться надовго в пам'яті місцевого населення та світової спільноти як гідний вчинок Людини із високими моральними принципами, відкритою світлою душею і благими намірами.

На пошану пам'яті греко-католицького священника Омеляна Ковча, 3 ініціативи директора Перемишлянського історико-краєзнавчого музею Домінчук Любові Остапівни та зберігача фондів Борбулевича Михайла Богдановича у 2012 р. в одній з кімнат створено експозицію, присвячену життю та діяльності пароха у Перемишлянах. Завдяки спогадам очевидців, ми маємо змогу отримати інформацію про життя та побут місцевого населення, взаємовідносини містян та о. Ковча, період перебування пароха у концтаборі «Майданек».

Остап Прибила у споминах про місто Перемишляни, громадську та душпастирську діяльність о. Еміліана Ковча згадує: «Перемишляни - це мале повітове містечко, яке 
адміністративно належало до воєводства Тернопіль. Населення менше 3000 осіб. Крім автохтонних українців, жили поляки євреї та кілька родин німців. До приходу священника Омеляна Ковча парафіяльний дім був дуже старим, занедбаним. Попередній священник о. Костельний був людиною мало енергійною, мало освіченою, русофілом. В місті був польський душпастир о. Більські, який своєю відданістю церкві, людяністю, зумів перетягнути до костела багатьох українців. Таку парафію дістав о. Еміліан Ковч [12, арк. 1].

Прихожани прийняли нового пароха від першої Служби Божої дуже тепло. О. Ковч був мужчиною середнього зросту, фізично добре збудований, стрункий, енергійний, високо освічений. Він був душпастирем за покликанням. Умів у проповідях поєднати релігію із піднесенням свідомості i набожності віруючих. На початках свого священнослужіння відновив церкву в середині і ззовні, перекрив новим дахом, долівку в середині виложив мозаїкою, придбав два дзвони. Запрошував кращих місіонерів, намагаючись підвищити набожність вірян.

За короткий термін часу заснував Народний дім, читальню, повітову кооперацію, Український банк. За таку діяльність містяни шанували і любили свого пароха, а тогочасна влада переслідувала його і відправляла до Бригідок, Золочева. До всіх людей відносився однаково. Як хоронив бідного жебрака, відправляв як над богачем, супроводжував на цвинтар.

Був великим оптимістом. Коли дружина запитала чи $є$ в нього гроші, щоб купити якихось харчів, він відповів, що немає, і додав: «Не журися, Бог нікого не забуває, то і про нас не забуде». Через деякий час повернувся додому, дав дружині гроші і каже: «Я тобі казав, що Бог про нас не забуде» [12, арк. 2].

В Перемишлянах завдяки авторитетові о. Ковча не було особистих порахунків, ані насильства. Німців на початку вітало майже все населення, крім євреїв. Незабаром німці організували самоуправу євреїв - т. зв. «Юденрад». Було здійснено реєстрацію євреїв чоловічого статі віком 16-55 років. Усім наказано прийти в певну годину на подвір'я гімназії, 700 чоловік розділили по 50, відправили в березину і розстріляли. В місті німці утворили гето, огородивши його високою кільчастою огорожею. На воротах прикріпили напис який заброняв людям неєврейської національності під карою смерті заходити в гето. о. Ковч нагадував своїм парафіянам мати в серці Бога та до брудної роботи (переслідувань євреїв, вбивств) не прикладати своїх рук. До закриття гето між євреями ходили чутки, що хто 3 них прийме Христову віру, того німці помилують. До Омеляна Ковча приходили євреї з проханням їх охрестити, і він їм не відмовляв» [12, арк. 5-6].

Про період перебування парохом міста Перемишляни Омеляна Ковча залишила свої теплі спогади Степанія Мацишин: «Я ходила до церкви святого Миколая у м. Перемишляни. Парохом був отець Омелян Ковч. 3 раннього дитинства пам'ятаю доброту і теплоту отця Ковча.

Як я росла, так і зі мною росла повага до доброго, лагідного, милосердного отця Ковча. В його домі бідні находили обід і матеріальну допомогу, слова потіхи і розради. Багатодітна сімя о. Ковча жила дуже скромно. Там не могло бути достатку, бо отець Ковч ділився своїми доходами з бідними парафіянами. Ні крихти жадності не було в отця Ковча, а тільки щедрість і милосердя» [11, арк. 1].

Про діяльність пароха міста Перемишляни міститься інформація у спогадах М. Шкільника: «Сімнадцять років я перебувавав на посаді судді у місті Перемишляни, яке було велике і бідне на українську інтелігенцію. Вона гуртувалася у товариства, приватні гуртки та ділилася своїми проблемами перебуваючи під окупаційною польською владою. О. Ковча, який очолював все організаційне життя в місті, вважали за «провідника всіх тих ворогів польської держави». Тому у всіх масових політичних акціях, які проводилися підпільною організацією (убивство куратора Собінського, напади на поштові карети, першим під підозру потрапляв Омелян Ковч. Під час кількамісячного ув'язнення у 
Беражанській в’язниці о. Ковч написав брошуру «Чому наші від нас втікають?», яка швидко розійшлася серед населення.

Він був прекрасним проповідником, його проповіді відзначалися не лише глибоким релігійним, але і патріотичним змістом. Він згадував в них актуальні події міста, надавав парафінам велику духовну підтримку і розраду в період польського гніту.

Однією 3 характерних рис пароха була безкористолюбність і цілковита незацікавленість матеріальними благами. Плату за похорони, шлюби, хрестини він покладав на добру волю парафіян. Ніколи о. Ковч і його дружина Марія-Анна не нарікали на скромне життя. Омелян Ковч ходив у латаній одежі священника, яку носив роками, таким вбогим він був аж до самої смерті [13, арк. 1].

3 приходом радянської влади в Галичину, почалася антирелігійна та антицерковна пропаганда, яка супроводжувалася переслідуванням священників, закриттям церков i монастирів, забороною навчання релігії в школах. Такі антирелігійні акції комуністичного режиму викликали хвилю обурення у о. Ковча. Місцеве населення жило в постійному страху, ночами НКВС проводив арешти чоловіків, їхні сім'ї вивозили в Сибір. Старців, дітей, хворих і калік садили у вагони, тримали закритими декілька днів на залізничній станції, не допускаючи нікого з продуктами харчування і водою. В цій ситуації О. Ковч став відважним Апостолом Правди. Він виголошував такі безстрашні проповіді в церкві, що навіть ті, які ніколи не заглядали до церкви, стали тепер постійно ходити на Богослужіння і слухали глибокі змістовні проповіді пароха, які їх розраджували i наповнювали вірою.

Такі діяння отця Ковча були відомі комуністичній партії, яка чекала слушної нагоди, щоб його ліквідувати. І така нагода сталася, коли перед відходом Червоної Армії прийшов наказ з Москви ліквідувати найдіяльніших українців, через те, що московські тирани думали, що німці проголосять Самостійність України. За декілька днів перед евакуацією міста енкаведисти здійснили провокацію, стріляючи під Народним домом і помешканням пароха. Це дало підставу для арешту всіх осіб, які перебували в Народному домі. Омелян Ковч побачив, що відбувається і втік на передмістя, переховувався у міщанина. Всіх заарештованих тоді українців, НКВС в ніч з 30 червня на 1 листопада 1941 р. жорстоко замордували» [13, арк. 2].

Про концтабір «Майданек» збереглися спогади Миколи Зацичного, який перебував там разом з Омеляном Ковчем. «Табір знаходився біля чотирьох кілометрів від Любліна. Сам табір ділився на п'ять піль. Кожне поле мало 22 бараки-блоки. В кожному бараці перебувало від 300 до 700 осіб. Бараки були настільки переповнені, що на кожному ліжку спало по 3-4 особи. Першими жителями табору були євреї, поляки, українці. Таборова адміністрація поблажливо відносилася до такої категорії в'язнів, як лікарі, інженери, механіки. Інша категорія в'язнів - професори, адвокати, священники, інспектори були приречені на смерть. Найбільше полонені боялися потрапити до шпиталю, бо там хворим допомагали померти, щоб дарма не витрачати харчів на них [10, арк. 1].

В першій половині вересня 1943 р. я працював на кухні третього поля і побачив в'язня, що важко пхав тачки із камінням. Він був босий, без шапки, без піджака, тільки в сорочці та штанах. Це був новоприбулий, бо лице і ноги були необпалені сонцем. На правій штанці нашитий номер і на червоному трикутнику видніла буква - ознака державної приналежності «Р» (польська). В'язень зупинився, щоб відпочити. Коли я запитав його, хто він і звідкіля приїхав, то у відповідь почув, що це о. Ковч, парох Перемишлян. Під арешт потрапив через те, що вихрестив євреїв на католицьку віру. Про свої вчинки Омелян Ковч ніколи не жалів, оскільки вважав це обов'язком кожного священника так поступати [10, арк. 1].

О. Ковча оприділили до праці в середині табору, де він виконував різноманітну роботу. В листопаді 1943 р. його перевели до картоплярні, де можна було крадькома з'їсти кусок сирої брукви чи моркви. Після Різдва 1944 р., при нашій зустрічі, Омелян Ковч був зажуреним, бо знав, що його відсилають до шпиталю. В другій половині березня 1944 р. 
адміністрація «Майданеку» почала готуватися до евакуації табору. Здорових в'язнів відсилали на захід до Бухенвальду чи до Гросс-Розен. Більше ніхто не бачив пароха Омеляна Ковча» [10, арк. 2]Під час перебування в Україні Папа Іван Павло II проголосив о. Ковча Блаженним мучеником. У 1999 р. Сврейська Рада України присвоїла йому звання «Праведник України» [6, с. 311]. 7 вересня 2008 р. за рішенням Священного Синоду Єпископів Української Греко-Католицької Церкви Патріарх Любомир Гузар проголосив Блаженного Священомученика Омеляна Ковча покровителем душпастирів Української Греко-Католицької Церкви [8, с. 100].

У 2010 р. за ініціативи Блаженнійшого кардинала Любомира Гузара затверджено «Статут відзнаки блаженного священномученика Омеляна Ковча». Відзнаку Блаженного Священномученика Омеляна Ковча встановлено для нагородження за значний внесок у справі екуменічного діалогу, діалогу культур i народів, міжрелігійного та міжнаціонального порозуміння, соціально-харитативної та благодійної діяльності, за особистий життєвий приклад жертовності та гуманізму, героїчні вчинки [4].

У місті Перемишляни відкрито меморіальну дошку (2002р.) та пам'ятник (2012р.) блаженному священномученику Омеляну Ковчу. 32012 р. за ініціативи духовенства Української Греко-Католицької Церкви щорічно організовуються прощі до містечка Перемишляни. Проща розпочинається 3 молебню до блаженного священномученика Омеляна Ковча, в храмі Святого Миколая, у якому він душпастирював.

Отже, більш ніж за двадцятирічний період перебування греко-католицьким священником містечка Перемишляни, отець Омелян Ковч зробив значний внесок у релігійне та суспільно-громадське життя міста. Завдяки своїй активній життєвій позиції, людяності, щирим проповідям Хрестової віри, йому вдалося отримати глибоку шану і повагу не тільки серед українців, але також і поляків, євреїв, німців. Незважаючи на перебування західноукраїнських земель під різними окупаційними режимами, Омелян Ковч зумів пронести любов до Бога, повагу до ближнього, стати захисником знедолених та зневірених людей, зберегти в душах вірян живий вогник віри та надії, врятувати від смерті значну кількість євреїв.

Його активна громадянська позиція, спрямовувалася на збереження української культури, про що свідчить діяльність у Перемишлянах Народного дому, міської організації «Пласт», драматичного гуртка, кооперативних курсів тощо. Вся його душпастирська та громадська діяльність була спрямована на служінню Богу та людям.

\section{ДЖЕРЕЛА ТА ЛІТЕРАТУРА}

1. Березанська Я. Отець Омелян Ковч - життя і суспільно-культурна діяльність // Сучасна гуманітаристика: збірник матеріалів I Міжнародної науково-практичної інтернетконференції, 28 квітня 2017 р. Переяслав-Хмельницький (Київ. обл.), 2017. Вип. 1. С. 123127.

2. Білас В. Омелян Ковч - священник концтабору Майданек. URL: https://www.istpravda.com.ua/columns/2010/12/21/10204/ (дата звернення: 18.10.2012).

3. Бірчак B., В'ятрович В. Омелян Ковч - священник, патріот та праведник. URL: https://www.istpravda.com.ua/articles/2019/03/26/153881/ (дата звернення: 27.03.2019).

4. Блаженний отець Омелян Ковч (20.08.1884-25.03.1944). URL: http://kovch.org.ua/ua/omelyan-kovch/career (дата звернення: 15.10.2017).

5. Горбачова К. Омелян Ковч: історія життя, як приклад світлої жертовності та гуманізму. URL: http://mij-kraj.com.ua/krinitsya-duhovnosti/omelian-kovch-istoriia-zhyttia (дата звернення: 28.04.2015).

6. Зеліско Л. Омелян Ковч: життя й духовний подвиг // Карпати: людина, етнос, цивілізація. 2014. Вип. 5. С. 308-312.

7. Ковба Ж.М. Людяність у безодні пекла. Поведінка місцевого населення Східної Галичини в роки «остаточного розв'язання єврейського питання». Видання третє, виправлене і доповнене. Київ, 2009. 296 с. 
8. Литвин С. Парох Майданека - отець Омелян Ковч // Воєнна історія. 2012. № 3(63). С. 94-100.

9. Мацелюх В. Блаженний отець Омелян Ковч // Грегіт: історико-краєзнавчотуристичний часопис, 2010-2011. Число 7. URL: http://www.voxpopuli.com.ua/rubriki/istoria/represiie-proti-cerkvi/blazennijotecomelankovcavtormaceluhvasil (дата звернення: 15.04.2012).

10. Перемишлянський історико-краєзнавчий музей. Спогади Зацичного М. [машинопис]. 2 арк.

11. Перемишлянський історико-краєзнавчий музей. Спогади Мацишин С.Й. [машинопис]. 1 арк.

12. Перемишлянський історико-краєзнавчий музей. Спогади Прибили О. Спомини про місто Перемишляни та діяльність громадську і душпастирську о. Еміліана Ковча. [машинопис]. 7 арк.

13. Перемишлянський історико-краєзнавчий музей. Спогади Шкільника М. [машинопис]. 5 арк.

14. Саківський I. Життя та діяльність Еміліана Ковча (1884-1939рр.) // Гілея: науковий вісник: зб. наук. пр. 2016. Вип. 105. С. 36-40.

15. Стасюк I.M., Гнідик I.I. Душпастирська діяльність отця Омеляна Ковча на території Перемишлянщини у $20-\mathrm{x}$ - на початку 40-х pp. XX ст. // Гілея: науковий вісник: зб. наук. пр. 2018. С. 66-72.

\section{REFERENCES}

1. Berezanska, Ya. (2017). Otets Omelian Kovch - zhyttia i suspilno-kulturna diialnist [Father Omelyan Kovch is a life and social and cultural activity]. Suchasna humanitarystyka Modern humanities: zbirnyk materialiv I Mizhnarodnoi naukovo-praktychnoi internetkonferentsii, 28 kvitnia 2017 r. (Vyp. 1), (pp. 123-127). Pereiaslav-Khmelnytskyi [in Ukrainian].

2. Bilas, V. (2012). Omelian Kovch - sviashchennyk kontstaboru Maidanek. [Omelyan Kovch is a priest of the Maydanek concentration camp]. www.istpravda.com.ua. Retrieved from https://www.istpravda.com.ua/columns/2010/12/21/10204/ [in Ukrainian].

3. Birchak, V. \& V'iatrovych, V. (2019). Omelian Kovch - sviashchennyk, patriot ta pravednyk [Omelyan Kovch is a priest, patriot and righteous person.]. www.istpravda.com.ua. Retrieved from https://www.istpravda.com.ua/articles/2019/03/26/153881/ [in Ukrainian].

4. Blazhennyi otets Omelian Kovch (20.08.1884-25.03.1944) [Blessed Father Omelyan Kovch (08/20/1884-25/03/1944).] kovch.org.ua. Retrieved from http://kovch.org.ua/ua/omelyankovch/career [in Ukrainian].

5. Horbachova, K. (2015). Omelian Kovch: istoriia zhyttia, yak pryklad svitloi zhertovnosti ta humanizmu [Omelyan Kovch: life story as an example of light sacrifice and humanism.]. mij-kraj.com.ua. Retrieved from http://mij-kraj.com.ua/krinitsyaduhovnosti/omelian-kovch-istoriia-zhyttia [in Ukrainian].

6. Zelisko, L. (2014). Omelian Kovch: zhyttia y dukhovnyi podvyh [Omelyan Kovch: life and spiritual feat]. Karpaty: liudyna, etnos, tsyvilizatsiia - Carpathians: human, ethnic, civilization, 5. 308-312 [in Ukrainian].

7. Kovba, Zh.M. (2009). Liudianist u bezodni pekla. Povedinka mistsevoho naselennia Skhidnoi Halychyny $v$ roky "ostatochnoho rozv'iazannia yevreiskoho pytannia» [Humanity in the abyss of hell. The behavior of the local population of Eastern Galicia in the years of the "final settlement of the Jewish question.»]. Kyiv [in Ukrainian].

8. Lytvyn, S. (2012). Parokh Maidaneka - otets Omelian Kovch [Maidanek's powder is Father Omelyan Kovch]. Voienna istoriia - Military history, 3(63), 94-100 [in Ukrainian].

9. Matseliukh, V. (2011). Blazhennyi otets Omelian Kovch [Blessed Father Omelyan Kovch]. Hrehit: istoryko-kraieznavcho-turystychnyi chasopys - Gregg: a history and tourism journal, 7. www.vox-populi.com.ua. Retried from http://www.vox- 
populi.com.ua/rubriki/istoria/represiie-proti-cerkvi/blazennijotecomelankovcavtormaceluhvasil [in Ukrainian].

10. Peremyshlianskyi istoryko-kraieznavchyi muzei. Spohady Zatsychnoho M. [Memories of Zacic M.]. [mashynopys] [in Ukrainian].

11. Peremyshlianskyi istoryko-kraieznavchyi muzei. Spohady Matsyshyn S.Y. [Memories Matsyshyn SI]. [mashynopys] [in Ukrainian].

12. Peremyshlianskyi istoryko-kraieznavchyi muzei. Spohady Prybyly O. Spomyny pro misto Peremyshliany ta diialnist hromadsku i dushpastyrsku o. Emiliana Kovcha [Memoirs of Pribili O. Memories of the town of Peremyshlyany and activities of public and pastoral Fr. Emilian Kovcha.]. [mashynopys] [in Ukrainian].

13. Peremyshlianskyi istoryko-kraieznavchyi muzei. Spohady Shkilnyka M. [Memoirs of the Schoolboy M.]. [mashynopys] [in Ukrainian].

14. Sakivskyi, I. (2016). Zhyttia ta diialnist Emiliana Kovcha (1884-1939 rr.) [The Life and Activities of Emilian Kovch (1884-1939)]. Hileia: naukovyi visnyk - Gilea: a scientific bulletin, 105, 36-40 [in Ukrainian].

15. Stasiuk, I.M. \& Hnidyk, I.I. (2018). Dushpastyrska diialnist ottsia Omeliana Kovcha na terytorii Peremyshlianshchyny u 20-kh - na pochatku 40-kh rr. XX st. [Pastoral activity of Father Omelyan Kovch in the territory of Peremyshlyans'k in the 1920's - early 40's of the XX century.] Hileia: naukovyi visnyk - Gilea: a scientific bulletin, 125, 66-72 [in Ukrainian].

Одержано 06.04.2019.

УДК 613.2:642.5](091)(477)«193»

Товкун Лідія,

кандидат історичних наук, доцент, доцент кафедри медико-біологічних дисциплін i валеології

tovkynlidiya@ukr.net

https://orcid.org/0000-0002-4091-1322

Researcher ID: W-5152-2018

Державний вищий навчальний заклад «Переяслав-Хмельницький державний педагогічний університет імені Григорія Сковороди», вул. Сухомлинського, 30, м. Переяслав-Хмельницький, Київська обл., Україна, 08401
DOI https://doi.org/10.31470/2415-35672019-46-173-182

\section{Tovkun Lidia,}

Candidate of Historical Sciences, Assistant Professor of the Department of Medical and Biological Disciplines and Valeology tovkynlidiya@ukr.net https://orcid.org/0000-0002-4091-1322 Researcher ID: W-5152-2018 Pereiaslav-Khmelnytskyi Hryhorii Skovoroda State Pedagogical University, 30, Sukhomlynsky Str., Pereiaslav-Khmelnytskyi, Kyiv region, Ukraine, 08401

\section{ВНЕСОК ВСЕУКРАЇНСЬКОГО ІНСТИТУТУ ХАРЧУВАННЯ В ПЛАНУВАННЯ ОРГАНІЗАЦЇ̈ ПІДПРИЕМСТВ ГРОМАДСЬКОГО ХАРЧУВАННЯ В УКРАЇНІ НА ПОЧАТКУ 30-Х pp. ХХ ст.}

Стаття висвітлює внесок Всеукраӥнського інституту харчування в планування організачії підприємств громадського харчування в Україні на початку 30-х рp. XX ст.

Встановлено, щз для складання норм харчування $i$ харчового балансу науковщі Всеукраїнського інституту харчування С. А. Томілін, О.Ф. Слінько, П. Т. Петров, 